Univerzitet u Beogradu
Poljoprivredni fakultet
Institut za poljoprivrednu tehniku
Naučni časopis
POLJOPRIVREDNA TEHNIKA
Godina XLIII
Broj 2, 2018.
Strane: $30-35$
Faculty of Agriculture
AGRICULTURAL ENGINEERING
Year XLIII
No. 2, 2018.
Pp: $30-35$

\title{
MANAGEMENT BY RESPECTING THE PROVISION OF CONDITIONS FOR THE COMMENCEMENT OF PROCUREMENT AND MONITORING OF IMPLEMENTATION IN AGRICULTURAL ENTERPRISES
}

\author{
Popović Slobodan', Laban Bogdan², Popović Vera ${ }^{3}$, Jovin Slobodanka ${ }^{4}$, \\ Grublješić Željko5 , Vladimir Filipović 6 \\ ${ }^{1}$ Assistant Professor, Internal Auditor, Department of Management and Finance, \\ Faculty of Economics and Engineering Management, Cvećarska 2, Novi Sad, Serbia, \\ Phone: +381640483 563, \\ ${ }^{2}$ Assistant Professor, Department of Management and Finance, Faculty of Economics \\ and Engineering Management, Cvećarska 2, Novi Sad, Serbia \\ ${ }^{3}$ Institute of Field and Vegetable Crops, Maksima Gorkog 30, Novi Sad, Srbija, \\ ${ }^{4}$ Ph.D., Professional Studies, High Business School of Novi Sad, Vladimira Perića \\ Valtera 4, Serbia, \\ ${ }^{5}$ Assistant Professor, PIM University Banja Luka, Banja Luka, Despota Stefana \\ Lazarevića BB, Bosnia and Hercegovina, \\ ${ }^{6}$ Institute for Medicinal Plants Research Dr Josif Pančić, Belgrade, Serbia.
}

Sažetak: Managing the use of securing the conditions for starting a procurement is one of the first corrections to successful management in terms of impacting the reduction of all inputs that enter the enterprise. It was also the first starting point of the author. The second starting point was to draw attention to the importance of monitoring the realization of procurement, contractual relations, etc. so that the company will have the opportunity to optimally affect the results. We established after testing on a representative medium-sized company that the total provision of conditions for starting the procurement procedure for the necessary assets of the company is 89 , over 13 set criteria at a given risk interval 1-10, or an average of 6.85 while in monitoring the overall security of contract realization and records on The 6 Criteria for Monitoring the Risk showed a total value of 26 and an average of 4.33 .

Corresponding author: slobodan.popovic49@gmail.com 
This just says that the first phase is marked as far as risk is concerned, and that in the coming period management should pay great attention to it in order to reduce the potential overall risk to the business of the company it is leading.

Ključne reči: management, procurement of goods, realization.

\section{INTRODUCTION}

Managing an enterprise requires combining different ways of improving work within the company itself. This changes the comprehensive working conditions of a large number of entities [1], which undoubtedly influences the changes in property values [2].

Numerous authors are trying to point out the specificity of production conditions [3]. It is necessary to respect it, but it is also necessary to draw attention to the evaluation [4], [5] regardless of how heterogeneous and varied it was in terms of real business.

Numerous authors point out that the existence of internal factors of the organization is very important for the overall management of overall management [6], [7], [8], [9] which can be seen through the evaluation of the company's activities in the market.

The end result of business activities is visible and measurable on the market, which many authors point out [10], [11], [12], above all through the financial evaluation of the company's undertaken activities. This is particularly evident in corporate governance [13], which is complicated by audit processes [14], that is, the effect on the level of medium and large companies [15].

\section{MATERIAL AND METHODS}

The paper analyzes the management of the agricultural enterprise through the testing of two conditions for improving the management of the company. The authors achieved this using the top management test in the selected agricultural enterprise.

The first level of testing included securing the conditions for starting the procurement through 13 selected issues, and the second was the analysis of the monitoring of the realization of procurement, contractual relations by asking 6 questions to the top management. In both cases, the risk assessment interval was 1-10, and the answer was yes, or no, in actual use.

The goal of these activities was to detect the risk movement in the two stages of the enterprise. The secondary goal was to discover the relationship between the two phases, which is more important for the future business of the entrepreneurs.

The overall overarching goal was to reveal the behavior of management in relation to the setting by testing risk. The research was done in the first half of 2018 in the medium-sized company, the main agricultural activity that exists in the territory of Novi Sad for more than 50 years. 


\section{RESULTS AND DISCUSSION}

Two frames were set up, firstly by analyzing the provision of conditions for starting the input in the company and monitoring the realization of the procurement. After the test, the author presented over three tables (1-3).

Table 1. Provision of conditions for the start of the procurement procedure for the necessary company assets

\begin{tabular}{|c|c|c|c|c|}
\hline \multirow[t]{2}{*}{$\begin{array}{l}\text { Serial } \\
\text { Number }\end{array}$} & \multirow[t]{2}{*}{ Description } & \multicolumn{2}{|c|}{$\begin{array}{l}\text { Responses } \\
\text { to the test }\end{array}$} & \multirow{2}{*}{$\begin{array}{l}\text { Risk } \\
\text { interval } \\
(1-10)\end{array}$} \\
\hline & & Yes & No & \\
\hline 1. & $\begin{array}{l}\text { Is the communication of the employees of the } \\
\text { procurement department via an e-mail regarding the } \\
\text { affairs of individual procurement can be checked at } \\
\text { the request of the company's management? }\end{array}$ & & No & 8 \\
\hline 2. & $\begin{array}{l}\text { Is there a system of financial management and } \\
\text { control established which would strengthen the } \\
\text { system of work of the procurement department and } \\
\text { the financial sector? }\end{array}$ & & No & 10 \\
\hline 3. & $\begin{array}{l}\text { Is there a established procedure (policy) of } \\
\text { advertising the decision to start collecting the needs } \\
\text { of the company's business units on the company } \\
\text { notice board? }\end{array}$ & & No & 7 \\
\hline 4. & $\begin{array}{l}\text { Is there a obligation to tone the session of the } \\
\text { Supervisory Board? }\end{array}$ & & No & 7 \\
\hline 5. & $\begin{array}{l}\text { Is there an obligation to fill in new employees in the } \\
\text { management? }\end{array}$ & & No & 8 \\
\hline 6. & $\begin{array}{l}\text { Is the President of the Procurement Commission } \\
\text { appointed to possess an expert qualification } \\
\text { corresponding to the subject of procurement? }\end{array}$ & & No & 8 \\
\hline 7. & $\begin{array}{l}\text { Does the company have a policy on the use of stamps } \\
\text { and stamps? }\end{array}$ & & No & 7 \\
\hline 8. & $\begin{array}{l}\text { Is there a rulebook on the movement of } \\
\text { documentation between the enterprise sector (in } \\
\text { particular between the finance and procurement } \\
\text { sectors)? }\end{array}$ & & No & 9 \\
\hline 9. & $\begin{array}{l}\text { Are employees familiar with the Law regulating the } \\
\text { affairs of Procurement? }\end{array}$ & Yes & & 5 \\
\hline 10. & $\begin{array}{l}\text { Are procurement department employees allowed } \\
\text { access to public databases that track legal changes in } \\
\text { procurement? }\end{array}$ & Yes & & 5 \\
\hline 11. & $\begin{array}{l}\text { Do the employees of the procurement department } \\
\text { have access to altered legal solutions in relation to } \\
\text { Procurement? }\end{array}$ & Yes & & 5 \\
\hline 12. & $\begin{array}{l}\text { Do they have a continuous communication with the } \\
\text { legal sector in connection with the performance of } \\
\text { Procurement Affairs? }\end{array}$ & Yes & & 5 \\
\hline
\end{tabular}




\begin{tabular}{|c|l|l|l|c|}
\hline 13. & $\begin{array}{l}\text { Does the communication of the employees of the } \\
\text { department of procurement with the general service } \\
\text { be done in writing through the office in connection } \\
\text { with the performance of an individual Procurement? }\end{array}$ & Yes & 5 \\
\hline Total risk & 89 \\
\hline
\end{tabular}

Table 2. Ensuring that records, monitoring of contract performance and reporting are done in accordance with regulations

\begin{tabular}{|c|l|l|l|c|}
\hline \multirow{2}{*}{$\begin{array}{c}\text { Serial } \\
\text { Number }\end{array}$} & \multicolumn{1}{|c|}{ Description } & \multicolumn{2}{|l|}{$\begin{array}{l}\text { Responses } \\
\text { to the test }\end{array}$} & \multicolumn{2}{l}{$\begin{array}{l}\text { Risk } \\
\text { interval } \\
\text { (1-10) }\end{array}$} \\
\cline { 3 - 5 } & & Yes & No & \\
\hline 1. & Is each individual procurement contract scanned? & Yes & & 5 \\
\hline 2. & $\begin{array}{l}\text { Is the individual procurement in the quarterly } \\
\text { procurement report of the company? }\end{array}$ & Yes & & 4 \\
\hline 3. & $\begin{array}{l}\text { Is the individual procurement included in the annual } \\
\text { procurement report? }\end{array}$ & Yes & & 3 \\
\hline 4. & $\begin{array}{l}\text { Is the individual procurement registered in the } \\
\text { department of procurement department? }\end{array}$ & Yes & & 5 \\
\hline 5. & $\begin{array}{l}\text { Is the individual procurement in the form of a copy of } \\
\text { the document delivered to the financial sector? }\end{array}$ & Yes & & 5 \\
\hline 6. & $\begin{array}{l}\text { Is the purchasing department's procurement opinion } \\
\text { required for a single procurement before the payment } \\
\text { of the financial sector? }\end{array}$ & Yes & & 26 \\
\hline
\end{tabular}

Table 3. Comparison of two different levels of security of conditions for possible improvement of corporate governance through overall risk

\begin{tabular}{|c|l|c|c|}
\hline No & \multicolumn{1}{|c|}{ Description } & \multicolumn{1}{|c|}{$\begin{array}{c}\text { Total } \\
\text { risk }\end{array}$} & $\begin{array}{c}\text { Average } \\
\text { risk }\end{array}$ \\
\hline 1. & $\begin{array}{l}\text { Provision of conditions for the start of the } \\
\text { procurement procedure for the necessary } \\
\text { company assets }\end{array}$ & 89 & 6,85 \\
\hline 2. & $\begin{array}{l}\text { Ensuring that records, monitoring of contract } \\
\text { performance and reporting are done in } \\
\text { accordance with regulations }\end{array}$ & 26 & 4,33 \\
\hline Total & \multicolumn{1}{|c|}{115} & \\
\hline
\end{tabular}

\section{CONCLUSIONS}

By this work, authors primarily draw attention to the importance of management by using the provision of conditions for the start of procurement as one of the essential corrections to a successful top-management in terms of influencing the reduction of all inputs that enter the enterprise. In addition, the authors emphasize the importance of the realization of procurement, contractual relations and drugs in order for top management of companies to have optimal business opportunities during the management of the company. 
We established after testing on a medium size medium-sized agricultural company that the total provision of conditions for starting the procurement procedure for the required assets of the company is 89 , over 13 criteria set at a given risk interval $1-10$, or an average of $6.85 \%$, while in monitoring the overall security of the contract realization and The records on the 6 criteria for monitoring the risk showed a total value of 26 and, on average, $4.33 \%$. The average risk of both phases is 5.59 and it is higher at $1.26 \%$ for the first investigated phase, while in the second phase it is $1.26 \%$ lower.

This is precisely the authors point out in this paper that the procurement phase and the provision of procurement conditions are remarkable and as far as risk management is concerned, the top management should in the following period pay great attention to it in order to reduce the potential overall risk to the business of the company it is leading. The risk of tracking the implementation is lower, but it should be kept under control so as not to increase.

\section{REFERENCES}

[1] Popović., S., (2014). Socio-ekonomski faktori ograničenja razvoja agrara, Monografija, Fimek, Novi Sad, p 30.

[2] Popović, S., Novaković, S., Đuranović, D., Mijić, R., Grublješić, Ž., Aničić, J. \& Majstorović, A. (2017). Application of international accounting standard-16 in a public company with predominantly agricultural activities, Economic Research-Ekonomska Istraživanja, Vol. 30, No. 1, 1850-1864.

[3] Popović S, Jovin S, Đuranović D, Popović V, Filipović V, Munitlak-Ivanović O, Grublješić Ž, Mijić R.(2017b). The Importance of Planting Pot Marigolds (Calendula officinalis L.) in degraded public spaces from the agroecological and economic perspective. Contemporary Agriculture, 66(1-2): 27-31.

[4] Gritsenko O.I. and Skorba O.A., (2015). Internal business control of service quality costs: managerial aspect, Actual problems of economics, 3, pp. 365-373.

[5] Panchuk P., (2015). Harmonization of accounting and taxation accounting at reporting formation on income. Actual problems of economy, pp. 373-379.

[6] Popović S., (2015). Implementacija heterogenih rizika u radu interne revizije, Revizor, 69, pp. 7-19.

[7] Popović S., Majstorović A., Grublješić Ž., (2015). Valuation of facilities in use and application of international accounting standards. Actual problems of economy, p. 379-387.

[8] Popović, S., (2015). Implementacija heterogenih rizika u radu interne revizije, Revizor, No. 69, pp.7-19.

[9] Popović, S., (2015). Interna revizija kao pokretač finansijske analize u javnim preduzećima RS, Revizor, 72, str. 41-53.

[10] Jovin, S. (2016). Financing obstacles of small enterprises-empirical analysis in the republic of Serbia. Teme, 3: 1101-1118.

[11] Jovin, S., Đukanović, S. (2012). Problemi finansijskog izveštavanja malih i srednjih preduzeća, Finansije, 252-270.

[12] Jovin, S. (2011). Business and Financial Support to Small and Medium Enterprises in Serbia. International Conference for Entrepreneurship, Innovation and Regional Development ICEIRD, 5-7 May, Ohrid, Macedonia, 1-7.

[13] Cantino, V. (2010). Korporativno uptravjanje, merenje performansi i normativna usaglašenost sistema internih kontrola, Data Status, Beograd, p. 17. 
[14] Majstorović A. and Popović S. (2015). Revizija poslovanja poljoprivrednog preduzeća, Računovodstvo, 1,77-85.

[15] Skrypnyk, M.I. and Vygivska I.M. (2015). Mortgage as one of the most effective types of collateral: accounting aspects, Actual problems of economics, No. 3(165) 388-393.

\title{
UPRAVLJANJE POMOĆU UVAŽAVANJA OBEZBEĐENJA USLOVA ZA POČETAK NABAVKI I PRAĆENJA REALIZACIJE U POLJOPRIVREDNIM PREDUZEĆIMA
}

\author{
Popović Slobodan ${ }^{1}$, Laban Bogdan ${ }^{2}$, Popović Vera ${ }^{3}$, Jovin Slobodanka ${ }^{4}$, \\ Grublješić Željko ${ }^{5}$, Vladimir Filipović ${ }^{6}$
}

${ }^{1}$ Docent, interni revizor, Fakultet za ekonomiju i industrijski menadžment, Cvećarska 2, Novi Sad, Srbija Phone: +381 640483 563, Corresponding author:

slobodan.popovic49@gmail.com,

${ }^{2}$ Docent, Fakultet za ekonomiju i industrijski menadžment, Cvećarska 2, Novi Sad, Srbija,

${ }^{3}$ Institut za ratarstvo i povrtarstvo, Maksima Gorkog 30, Novi Sad, Srbija,

${ }^{4}$ Visoka poslovna škola Vladimira Perića Valtera 4, Novi Sad, Srbija,

${ }^{5}$ Docent, Univerzitet za poslovni inžinjering i menadžment, Banja Luka, Despota Stefana Lazarevića $B B, B i H$,

${ }^{6}$ Institut za lekovito bilje Josif Pančić, Beograd, Srbija.

Sažetak: Upravljanje uz korišćenje obezbeđenja uslova za početak nabavki je jedan od prvih korektiva uspešnom menadžmentu u smislu uticanja na smanjivanje svih inputa koji ulaze u preduzeće. To je bila i prvo polazište autora. Drugo polazište je bilo skretanje pažnje na značaj praćenja realizacije nabavke, ugovornih odnosa i dr. kako bi preduzeće imalo mogućnosti za optimalno efektuiranje rezultata. Utvrdili smo nakon testiranja na reprezentativnom preduzeću srednje veličine da ukupno obezbeđeni uslova za početak postupka nabavke potrebnih dobara preduzeća iznose 89, preko 13 postavljenih kriterijuma na datom intervalu rizika 1-10, odnosno prosečno 6,85 dok kod praćenja ukupne obezbeđenosti realizacije ugovora i evidencije na 6 kriterijuma praćenja rizik je pokazivao ukupnu vrednost od 26 odnosno prosečno 4,33. To upravo govori da je prva faza izrazita što se tiče rizika i da u narednom periodu menadžment treba da joj pokloni veliku pažnju kako bi smanjio mogući ukupni rizik po poslovanje preduzeća koga vodi.

Ključne reči: upravljanje, nabavka robe, realizacija.

Prijavljen:

Submitted:

10.06.2018.

Ispravljen:

Revised:

20.06.2018

Prihvaćen:

Accepted:

26.06.2018. 